\title{
Effects of Different Tillage, Rotation Systems and Nitrogen Levels on Wheat Yield and Nitrogen Use Efficiency
}

\author{
Nihal Kayan",a,*, Nazife Gözde Ayter-Arpacıŏ̆lu,b, İmren Kutlu,c, Mehmet Sait Adak ${ }^{3, d}$ \\ ${ }^{1}$ Department of Field Crops, Faculty of Agriculture, Eskisehir Osmangazi University, 26480 Eskisehir, Turkey \\ ${ }^{2}$ Department of Biosystem Engineering, Faculty of Agriculture, Eskisehir Osmangazi University, 26480 Eskisehir, Turkey \\ ${ }^{3}$ Department of Field Crops, Faculty of Agriculture, Ankara University, 06100 Ankara, Turkey \\ *Corresponding author
}

A R T I C L I N F O A B S T R A C T

Research Article

This research was conducted between 2011 and 2015 at research field of Faculty of Agriculture, Eskişehir Osmangazi University for evaluating two tillage methods (conventional and reduced), three crop rotations (wheat-wheat; wheat-fallow; wheat-chickpea) and four $\mathrm{N}$ levels $(0,50,100$,

Received : 25/07/2019

Accepted : 21/07/2020 $\left.150 \mathrm{~kg} \mathrm{ha}^{-1}\right)$. The experimental design was split-split plot with three replicates. Tillage methods were in main plots, crop rotations in subplots and $\mathrm{N}$ levels in sub-sub plots. The $\mathrm{N}$ concentration of grain and straw harvested from aboveground plant organs was separately determined using by the Kjeldahl digestion method after the plant samples were ground. Then, grain protein content, nitrogen use efficiency (NUE), nitrogen uptake efficiency (NUPE), nitrogen utilization efficiency (NUTE) were calculated. According to results, effects of tillage methods on NUE were unclear. Conventional tillage methods resulted in higher NUPE than reduced tillage in the last three years

Keywords: Crop Rotation Grain Yield Nitrogen Levels Nitrogen Use Efficiency Soil Tillage of the experiment. The NUTE was higher in reduced tillage than conventional in 2011-2012 and 2014-2015. The effects of tillage methods on grain yield were different due to the climatic conditions. Wheat-chickpea rotation had the better results for examined traits in this research. Increasing nitrogen doses increased grain and plant protein rate, however it decreased NUE and NUPE. The effects of nitrogen doses on NUTE were ambiguous. Nitrogen use efficiency and NUPE is traits that can be differed according to changeable grain yield depend on environmental conditions. Therefore, the experiments should be conducted for more than four years for revealed absolute effects both soil tillage method and nitrogen fertilization.

nkayan@ogu.edu.tr ikutlu@ogu.edu.tr https://orcid.org/0000-0001-7505-0959 https://orcid.org/0000-0002-3505-1479 gayter@ogu.edu.tr adak@agri.ankara.edu.tr https://orcid.org/0000-0002-5121-4303 Ditps://orcid.org/0000-0002-0154-3328

\section{Introduction}

The cereal-fallow crop rotation is most common method in Central Anatolia region which are greatly contributing to the country for agriculture (Baskan and Unver, 2000). The ways of obtaining crop every year from the fallow fields have been sought since years due to increased demand for the agricultural crops in parallel with the growing population. About $11-23 \%$ of the annual rainfall in Central Anatolia is accumulated in the fallow years in suitable climate conditions (Genctan, 2015). Whether or not it would be appropriate to leave the lands empty for one year for accumulating such a low amount of moisture is discussed. It is known that $80-100 \%$ of the water held in soil during fallow period is usually lost by evaporation from soil surface. In addition, water accumulation efficiency of less than $90 \mathrm{~cm}$ deep soils is less (Genctan, 2015). For this reason, it would be more appropriate for uses the water by plants instead of disappearing by evaporation.
The dry farming areas are poor of organic matters because of fallow-wheat crop rotation. Moreover, in consequence of mono-culture agricultural system, soil compression leads to a deformation of physical construction and reduction of aeration of soils in longterm. These cases as advanced, the accumulation of $\mathrm{CO} 2$ and other matters in the soil is decreased. Also, due to roots exposed to damage, the water absorption by plants, biological nitrogen fixation and microbiological activity decrease. If deep-rooted plants is used to crop rotation, these inconveniences are eliminated (Thériault et al., 2019). Legumes are very important plants for the fallow fields to utilization effectively. Because, the legumes are deep-root plants (up to $1.5-2.0 \mathrm{~m}$ ) and their roots till the soil deeply and leave an organic matter - rich soil for following sowing season. The annual legumes planted at the fallow area leave less humidity and the same amount 
inorganic nitrogen for wheat to be planted next, when compared the fallow (Kun et al., 1990).

The tillage systems are classified in two main groups: traditional tillage and conservation tillage. Soil, water and energy are not conservation in the traditional tillage systems (Ghiyasi et al., 2016). The labour, energy and cost are minimized in the conservation tillage and adequate stubble is left in the field for the protection of water and soil. The conservation tillage mostly applies as minimum tillage or no-tillage sowing and plough is not uses in these tillage methods (Jabran and Aulakh, 2015).

A good genotype uses the nitrogen for grain yield rather than stem by taking high nitrogen in from the soil and fertilizers. Nitrogen use efficiency (NUE) is generally defined as the grain yield produced per unit of $\mathrm{N}$ available from the soil and fertilizer (Moll et al., 1982). Nitrogen use efficiency is an indicator for increased yield in low - input sustainable agriculture, minimized fertilizer cost and to reduce harmful effects of excessive fertilization. Moll et al. (1982) reported that both nitrogen uptake efficiency (NUPE) and nitrogen utilization efficiency (NUTE) is supportive for NUE.

In this study, the use of two tillage systems (conventional and reduced), three crop rotations (wheatwheat; wheat-fallow; wheat-chickpea) and four $\mathrm{N}$ levels $\left(0,50,100,150 \mathrm{~kg} \mathrm{ha}^{-1}\right)$ were evaluated in Central Anatolia Region for four year and to determine of the effects of tillage, crop rotation and $\mathrm{N}$ doses on the grain yield and NUE was aimed.

\section{Material and Methods}

The research was conducted during to four years (20112015) at the experimental area of Faculty of Agriculture, Eskisehir Osmangazi University, Eskisehir, Turkey (39 ${ }^{\circ}, 48^{\prime} \mathrm{N}$; 30³1' E, $798 \mathrm{~m}$ above sea level). Monthly and annual precipitation and temperature during the experimental period and long term for Eskisehir are given
Figure 1. According to the results of soil analysis, some of the physical and chemical properties of the experimental area are presented in Table 1.

The study was evaluated effects of on the wheat grain yield and NUE using two tillage methods [conventional tillage (CT) and reduced tillage (RT)], three crop rotations [wheat-wheat (WW); wheat-fallow (WF); wheat-chickpea (WC)] and four $\mathrm{N}$ levels $\left.\left(0,50,100,150 \mathrm{~kg} \mathrm{ha}^{-1}\right)\right]$. The experimental design was split split plot with three replicates. Tillage method was in main plots, crop rotation in sub plots and $\mathrm{N}$ fertilizer in sub-sub plots.

The conventional tillage included mouldboard ploughing followed by one passes of a sweep plowing and/or rototiller cultivation to provide a proper seedbed. The reduced tillage included only sweep plowing and/or rototiller cultivation. Tillage depths for CT and RT were 25-30 and 8-10 cm, respectively. Tillage treatments were made in September in all years, however, no-planting plots were tilled by rototiller for weeds when chickpea sown (in spring). Wheat was sown all of the plots in the first and third year. In the second and fourth year, the experimental area was consisted of wheat planted plots to $1 / 3$ part, chickpea planted plots to $1 / 3$ part and fallow to $1 / 3$ part.

Fertilization was applied to $60 \mathrm{~kg} \mathrm{ha}^{-1} \mathrm{P}_{2} \mathrm{O}_{5}$ as TSP (46\%) to all plots on wheat. The nitrogen was applied as ammonium nitrate, half of $\mathrm{N}$ at the sowing, and the remaining $\mathrm{N}$ as top-dressed at the beginning of the wheat stem elongation. $20 \mathrm{~kg} \mathrm{ha}^{-1} \mathrm{~N}$ (ammonium nitrate) and 60 $\mathrm{kg} \mathrm{ha}^{-1} \mathrm{P}_{2} \mathrm{O}_{5}$ [TSP (46\%)] applied as basal fertilization to all sub-subplots in the chickpea sowing time.

Each sub-subplot was $12 \mathrm{~m}^{2}$ (4 m x $3 \mathrm{~m}$ ). Wheat (cv. Sönmez) was sown with mechanical seeder to $18 \mathrm{~cm}$ row spacing, the rate of 600 seeds $\mathrm{m}^{-2}$ at on 8 October 2011, on 12 October 2012, on 11 October 2013 and on 21 October 2014. Weed control was made with 2,4Dichlorophenoxyacetic acid, a chemical herbicide, in early spring.

Table 1. Physical and chemical properties of the soil at the experimental years.

\begin{tabular}{c|ccccccccc}
\hline Year & $\begin{array}{c}\text { Depth } \\
(\mathrm{cm})\end{array}$ & Texture & $\mathrm{pH}$ & $\begin{array}{c}\text { Total salt } \\
(\%)\end{array}$ & $\begin{array}{c}\text { Lime } \\
(\%)\end{array}$ & $\begin{array}{c}\text { Organic matter } \\
(\%)\end{array}$ & $\begin{array}{c}\mathrm{P}_{2} \mathrm{O}_{5} \\
\left(\mathrm{~kg} \mathrm{ha}^{-1}\right)\end{array}$ & $\begin{array}{c}\mathrm{K}_{2} \mathrm{O} \\
\left(\mathrm{kg} \mathrm{ha}^{-1}\right)\end{array}$ & $\begin{array}{c}\mathrm{N} \\
(\%)\end{array}$ \\
\hline $2011-12$ & $0-30$ & loamy & 8.04 & 0.057 & 3.7 & 0.98 & 60.6 & 3411.1 & 0.04 \\
$2012-13$ & $0-30$ & loamy & 7.99 & 0.064 & 3.6 & 1.18 & 34.9 & 2258.6 & 0.05 \\
$2013-14$ & $0-30$ & loamy & 7.80 & 0.079 & 5.8 & 1.38 & 43.1 & 2151.1 & 0.06 \\
$2014-15$ & $0-30$ & loamy & 7.46 & 0.020 & 5.4 & 1.63 & 65.3 & 3630.0 & 0.07 \\
\hline
\end{tabular}

$\underline{\text { Table 2. Effect of different tillage methods and nitrogen levels on some charecters of wheat in 2011-2012 growing season. }}$

\begin{tabular}{l|cccccc}
\hline \multicolumn{1}{c|}{ Treatments } & GPR & PPR & NUE & NUPE & NUF & GY \\
\hline Conventional tillage & 12.13 & 1.95 & 62.3 & 13.74 & $50.92^{\mathrm{B}}$ & 3876.9 \\
Reduced tillage & 12.00 & 1.95 & 66.1 & 14.08 & $226.34^{\mathrm{A}}$ & 3868.1 \\
Mean & 12.06 & 1.95 & 64.2 & 13.91 & 138.63 & 3872.5 \\
\hline $0 \mathrm{~kg} \mathrm{ha}^{-1} \mathrm{~N}$ & $11.43^{\mathrm{b}}$ & 1.86 & & & $3743.4^{\mathrm{b}}$ \\
$50 \mathrm{~kg} \mathrm{ha}^{-1} \mathrm{~N}$ & $12.05^{\mathrm{ab}}$ & 1.84 & 56.9 & $15.72^{\mathrm{a}}$ & $86.42^{\mathrm{C}}$ & $3564.9^{\mathrm{b}}$ \\
$100 \mathrm{~kg} \mathrm{ha}^{-1} \mathrm{~N}$ & $12.28^{\mathrm{a}}$ & 2.06 & 66.6 & $11.30^{\mathrm{b}}$ & $153.43^{\mathrm{B}}$ & $3904.4^{\mathrm{ab}}$ \\
$150 \mathrm{~kg} \mathrm{ha}^{-1} \mathrm{~N}$ & $12.51^{\mathrm{a}}$ & 2.03 & 69.2 & $14.72^{\mathrm{a}}$ & $176.05^{\mathrm{A}}$ & $4277.4^{\mathrm{a}}$ \\
Mean & 12.06 & 1.95 & 64.2 & 13.91 & 138.63 & 3872.5 \\
\hline Tillage & $\mathrm{ns}$ & $\mathrm{ns}$ & $\mathrm{ns}$ & $\mathrm{ns}$ & $* *$ & $\mathrm{~ns}$ \\
$\mathrm{~N}$ doses & $*$ & $\mathrm{~ns}$ & $\mathrm{~ns}$ & $*$ & $* *$ & $*$ \\
Tillage $\times \mathrm{N}$ doses & $\mathrm{ns}$ & $\mathrm{ns}$ & $* *$ & $* *$ & $* *$ & $\mathrm{~ns}$ \\
\hline
\end{tabular}

GBR: Grain protein ratio (\%); PPR: Plant protein ratio (\%); NUE: Nitrogen use efficiency (kg ha-1); NUPE: Nitrogen uptake efficiency (kg ha-1); NUF: Nitrogen utilization efficiency (kg ha-1); GY: Grain yield (kg ha-1); ns: non significant, *: $\mathrm{P} \leq 0.05$, **: $\mathrm{P} \leq 0.01$. 
Table 3. Effect of different tillage methods and nitrogen levels on some charecters of wheat in 2012-2013 growing season.

\begin{tabular}{lcccccc}
\hline Treatments & GPR & PPR & NUE & NUPE & NUF & GY \\
\hline Conventional tillage & $11.92^{\mathrm{A}}$ & $2.99^{\mathrm{A}}$ & $48.3^{\mathrm{B}}$ & $33.53^{\mathrm{a}}$ & 56.94 & $2823.5^{\mathrm{b}}$ \\
Reduced tillage & $10.30^{\mathrm{B}}$ & $2.13^{\mathrm{B}}$ & $129.1^{\mathrm{A}}$ & $17.68^{\mathrm{b}}$ & 59.66 & $4071.7^{\mathrm{a}}$ \\
Mean & 11.11 & 2.56 & 88.7 & 25.60 & 58.30 & 3447.6 \\
\hline $0 \mathrm{~kg} \mathrm{ha}^{-1} \mathrm{~N}$ & $10.10^{\mathrm{B}}$ & $1.59^{\mathrm{D}}$ & - & - & - & $3320.2^{\mathrm{bc}}$ \\
$50 \mathrm{~kg} \mathrm{ha}^{-1} \mathrm{~N}$ & $11.39^{\mathrm{A}}$ & $2.20^{\mathrm{C}}$ & $115.7^{\mathrm{A}}$ & $40.62^{\mathrm{A}}$ & $20.95^{\mathrm{C}}$ & $3551.0^{\mathrm{ab}}$ \\
$100 \mathrm{~kg} \mathrm{ha}^{-1} \mathrm{~N}$ & $11.28^{\mathrm{A}}$ & $2.69^{\mathrm{B}}$ & $72.9^{\mathrm{B}}$ & $24.53^{\mathrm{B}}$ & $67.45^{\mathrm{B}}$ & $3218.0^{\mathrm{c}}$ \\
$150 \mathrm{~kg} \mathrm{ha}^{-1} \mathrm{~N}$ & $11.67^{\mathrm{A}}$ & $3.77^{\mathrm{A}}$ & $77.5^{\mathrm{B}}$ & $11.67^{\mathrm{C}}$ & $86.50^{\mathrm{A}}$ & $3701.1^{\mathrm{a}}$ \\
Mean & 11.11 & 2.56 & 88.7 & 25.60 & 58.30 & 3447.6 \\
\hline Tillage & $* *$ & $* *$ & $* *$ & $*$ & $\mathrm{~ns}$ & $*$ \\
$\mathrm{~N}$ doses & $* *$ & $* *$ & $* *$ & $* *$ & $* *$ & $*$ \\
Tillage $\times \mathrm{N}$ doses & $* *$ & $* *$ & $* *$ & $\mathrm{~ns}$ & $* *$ & $*$ \\
\hline
\end{tabular}

GBR: Grain protein ratio (\%); PPR: Plant protein ratio (\%); NUE: Nitrogen use efficiency (kg ha-1); NUPE: Nitrogen uptake efficiency (kg ha-1); NUF: Nitrogen utilization efficiency (kg ha-1); GY: Grain yield (kg ha-1); ns: non significant, *: $\mathrm{P} \leq 0.05$, **: $\mathrm{P} \leq 0.01$.
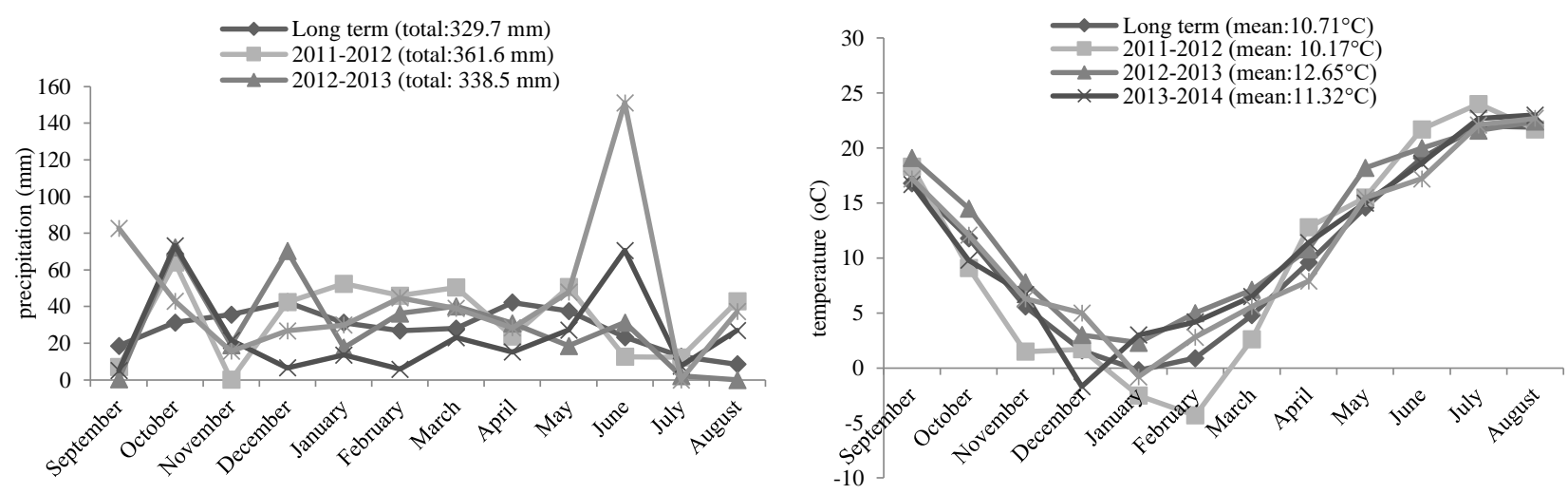

Figure 1. Total rainfall and monthly mean temperature for four seasons at Eskişehir, Turkey
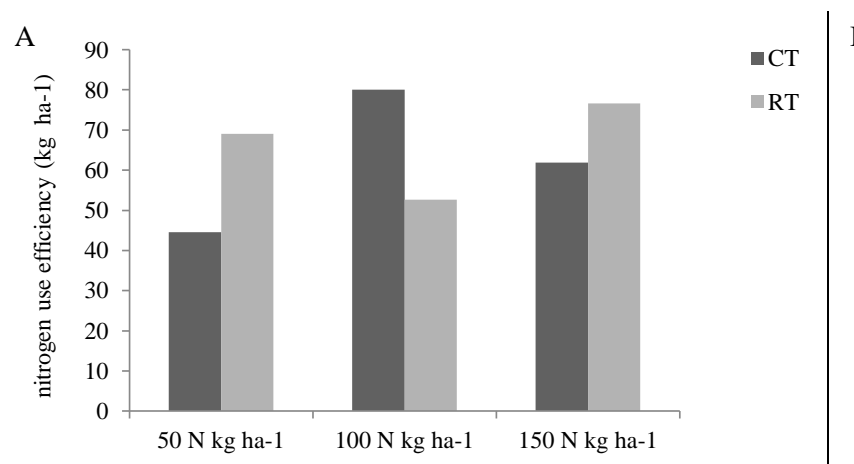

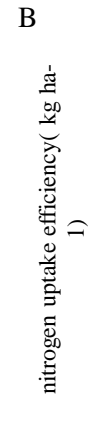

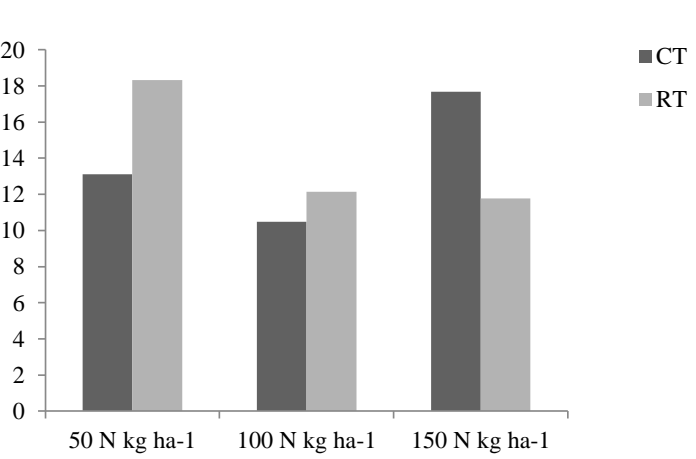

Figure 2. The interaction between tillage methods and $\mathrm{N}$ levels on nitrogen use efficiency (A) and nitrogen uptake efficiency (B) of wheat in 2011-2012[ LSD1\%: 2.756 (A); LSD1\%: 0.559 (B)]

Wheat plants were harvested separately in all sub subplots, on 23 July 2012, on 8 July 2013, on 9 July 2014, on 22 July 2015. The yields of each sub-subplot were found by blending and weighing. The $\mathrm{N}$ concentration of grain and straw was separately determined using by the micro Kjeldahl digestion method after the plant samples were ground. Then, grain protein ratio and plant protein ratio were obtained by multiplying 6.25 (Jones, 1981).

The NUE, NUPE and NUTE were calculated according to Moll et al. (1982), Sowers et al. (1994) and Delagu et al. (1998) by following formulas.

$\mathrm{NUE}=\left[\right.$ yield at $\mathrm{N} \times\left(\mathrm{kg} \mathrm{ha}^{-1}\right)-$ yield at $\left.\mathrm{N}_{0}\left(\mathrm{~kg} \mathrm{ha}^{-1}\right)\right] /$ applied $\mathrm{N}\left(\mathrm{kg} \mathrm{ha}^{-1}\right)$.

NUPE $=\left[\right.$ total aboveground plant $\mathrm{N}$ at $\mathrm{N} \times\left(\mathrm{kg} \mathrm{ha}^{-1}\right)-$ total aboveground $\mathrm{N}$ at $\left.\mathrm{N}_{0}\left(\mathrm{~kg} \mathrm{ha}^{-1}\right)\right]$ / applied $\mathrm{N}\left(\mathrm{kg} \mathrm{ha}^{-1}\right)$.

NUTE $=\left[\right.$ yield at $\mathrm{N} \times\left(\mathrm{kg} \mathrm{ha}^{-1}\right)-$ yield at $\left.\mathrm{N}_{0}\left(\mathrm{~kg} \mathrm{ha}^{-1}\right)\right] /$ [total aboveground plant $\mathrm{N}$ at $\mathrm{N} \times\left(\mathrm{kg} \mathrm{ha}^{-1}\right)$ - total aboveground plant $\mathrm{N}$ at $\left.\mathrm{N}_{0}\left(\mathrm{~kg} \mathrm{ha}^{-1}\right)\right]$.
All data were subjected to analysis of variance based on General Linear Model using the Statview package (SAS Institute). Means were compared by Least Significant Differences (LSD) test.

\section{Results and Discussion}

\section{Tillage}

The grain and plant protein ratio were higher in conventional tillage than reduced tillage during the 20122013 growing season while only plant protein ratio were higher in conventional tillage than reduced tillage during the 2013-2014 growing season (Table 3,4). Some researchers (Lopez-Bellido et al., 1998; Ruisi et al., 2016) reported that higher grain protein ratio was obtained at the conventional tillage, the others (Ali et al., 2019; Ruiz et al., 2019) at the zero tillage. Adak and Birsin (2000) noticed that the grain protein ratio at the conventional tillage was 
higher in comparison to reduced tillage. The "tillage $x$ nitrogen doses" interaction was statistically significant in the second year (Figure 4A, 4B). The highest values of grain and plant protein ratio obtained from $150 \mathrm{~kg} \mathrm{ha}^{-1} \mathrm{~N}$ levels in the conventional tillage. While $0 \mathrm{~kg} \mathrm{~N} \mathrm{ha}^{-1}$ dose had higher grain protein ratio all of the plots, in the third growing season, it had the lowest value on reduced tillage and wheat-wheatwheat crop rotation. The highest plant protein ratio was obtained from the conventional tillage, wheat - chickpea crop rotation system and $150 \mathrm{~kg} \mathrm{ha}^{-1} \mathrm{~N}$ levels, while $150 \mathrm{~kg}$ $\mathrm{N}$ ha $^{-1}$ caused quite low value at the reduced tillage and wheat - fallow crop rotation systems. For this reason, "tillage $\mathrm{x}$ crop rotation $\mathrm{x}$ nitrogen doses" interaction was significant (Figure 7A and 7B). Reduced tillage and $50 \mathrm{~kg} \mathrm{ha}^{-1} \mathrm{~N}$ level were caused the highest plant protein ratio all of the plots in the fourth growing season, while the conventional tillage methods showed the highest value in $100 \mathrm{~kg} \mathrm{ha}^{-1} \mathrm{~N}$ level. Therefore, "tillage $\mathrm{x}$ nitrogen dose" interaction was significant significantly (Figure 10A).

The NUE was higher in the reduced tillage than conventional tillage in 2012-2013 growing season however in 2013-2014 growing season was vice versa (Table 3, 4).
Nitrogen use efficiency might be high due to high grain yield in these tillage methods (Nitrogen use efficiency: Grain yield / applied N). Devi et al. (2015) reported that the NUE is higher in zero tillage than in conventional tillage. The NUE was decreased in the conventional tillage and $150 \mathrm{~kg} \mathrm{ha}^{-1} \mathrm{~N}$ levels, while NUE was increased in reduced tillage and same $\mathrm{N}$ dose in first growing season. This condition was resulted significant "tillage $\mathrm{x}$ nitrogen dose" interaction (Figure 2A). In the second growing season, the reason of this significant interaction was higher NUE in reduced tillage and $50 \mathrm{~kg} \mathrm{ha}^{-1} \mathrm{~N}$ level and lower values in the conventional tillage and $50 \mathrm{~kg} \mathrm{ha}^{-1} \mathrm{~N}$ doses (Figure 5A). The highest NUE value in the conventional tillage, wheat - chickpea rotation system and $100 \mathrm{~kg} \mathrm{ha}^{-1} \mathrm{~N}$ levels in third growing season, but the same nitrogen dose had lower values at other plots. Tillage $\mathrm{x}$ crop rotation $\mathrm{x}$ nitrogen dose interaction was significant (Figure 8A). While $50 \mathrm{~kg} \mathrm{ha}^{-1} \mathrm{~N}$ levels showed superior performance under conventional tillage for NUE in fourth growing season, the same tillage methods showed lower value in the other plots. For this reason, tillage $\mathrm{x}$ nitrogen dose interaction was significant (Figure 10B).

Table 4. Effect of different tillage methods, crop rotations and nitrogen levels on some charecters of wheat in 2013-2014 growing season.

\begin{tabular}{|c|c|c|c|c|c|c|}
\hline Treatments & GPR & PPR & NUE & NUPE & NUF & GY \\
\hline Conventional tillage & 13.93 & $4.13^{\mathrm{A}}$ & $30.5^{\mathrm{A}}$ & $5.19^{\mathrm{a}}$ & 332.19 & $1283.5^{\mathrm{A}}$ \\
\hline Reduced tillage & 13.89 & $3.39^{\mathrm{B}}$ & $24.1^{\mathrm{B}}$ & $4.14^{\mathrm{b}}$ & 336.90 & $935.6^{\mathrm{B}}$ \\
\hline Mean & 13.91 & 3.76 & 27.30 & 4.66 & 334.54 & 1109.5 \\
\hline Wheat-Wheat & $12.91^{\mathrm{B}}$ & $3.52^{\mathrm{C}}$ & $25.3^{\mathrm{B}}$ & $6.64^{\mathrm{A}}$ & $90.87^{\mathrm{C}}$ & $1173.0^{\mathrm{A}}$ \\
\hline Wheat-Fallow & $14.20^{\mathrm{AB}}$ & $3.68^{\mathrm{B}}$ & $18.7^{\mathrm{C}}$ & $2.68^{\mathrm{C}}$ & $601.99^{\mathrm{A}}$ & $990.1^{\mathrm{B}}$ \\
\hline Wheat-Chickpea & $14.62^{\mathrm{A}}$ & $4.08^{\mathrm{A}}$ & $38.1^{\mathrm{A}}$ & $4.67^{\mathrm{B}}$ & $310.78^{\mathrm{B}}$ & $1165.6^{\mathrm{A}}$ \\
\hline Mean & 13.91 & 3.76 & 27.30 & 4.66 & 334.54 & 1109.5 \\
\hline $0 \mathrm{~kg} \mathrm{ha}^{-1} \mathrm{~N}$ & $13.00^{\mathrm{C}}$ & $3.46^{\mathrm{C}}$ & & & & $1115.6^{\mathrm{B}}$ \\
\hline $50 \mathrm{~kg} \mathrm{ha}^{-1} \mathrm{~N}$ & $13.82^{\mathrm{B}}$ & $3.56^{\mathrm{C}}$ & $37.3^{\mathrm{A}}$ & $7.32^{\mathrm{A}}$ & $267.74^{\mathrm{B}}$ & $1034.2^{\mathrm{C}}$ \\
\hline $100 \mathrm{~kg} \mathrm{ha}^{-1} \mathrm{~N}$ & $14.26^{\mathrm{AB}}$ & $3.90^{\mathrm{B}}$ & $31.2^{\mathrm{B}}$ & $4.28^{\mathrm{B}}$ & $441.86^{\mathrm{A}}$ & $1192.2^{\mathrm{A}}$ \\
\hline $150 \mathrm{~kg} \mathrm{ha}^{-1} \mathrm{~N}$ & $14.54^{\mathrm{A}}$ & $4.13^{\mathrm{A}}$ & $13.5^{\mathrm{C}}$ & $2.39^{\mathrm{C}}$ & $294.04^{\mathrm{B}}$ & $1096.2^{\mathrm{BC}}$ \\
\hline Mean & 13.91 & 3.76 & 27.30 & 4.66 & 334.54 & 1109.5 \\
\hline Tillage & ns & $* *$ & $* *$ & $*$ & $\mathrm{~ns}$ & $* *$ \\
\hline Crop rotation & $* *$ & $* *$ & $* *$ & $* *$ & $* *$ & $* *$ \\
\hline $\mathrm{N}$ doses & $* *$ & $* *$ & $* *$ & $* *$ & $* *$ & $* *$ \\
\hline Tillge $\times$ crop rot. & ns & $* *$ & $* *$ & $* *$ & $* *$ & $* *$ \\
\hline Tillage $\times \mathrm{N}$ doses & ns & $* *$ & $* *$ & $* *$ & $* *$ & $* *$ \\
\hline Crop rot. $\times \mathrm{N}$ doses & $* *$ & $* *$ & $* *$ & $* *$ & $* *$ & $* *$ \\
\hline Till. $\times$ crop rot. $\times \mathrm{N}$ dose & $* *$ & $* *$ & $* *$ & $* *$ & $* *$ & $* *$ \\
\hline
\end{tabular}

GBR: Grain protein ratio (\%); PPR: Plant protein ratio (\%); NUE: Nitrogen use efficiency (kg ha-1); NUPE: Nitrogen uptake efficiency (kg ha-1); NUF: Nitrogen utilization efficiency (kg ha-1); GY: Grain yield (kg ha-1); ns: non significant, *: $\mathrm{P} \leq 0.05, * *: \mathrm{P} \leq 0.01$.

Table 5. Effect of different tillage methods and nitrogen levels on some charecters of wheat in 2014-2015 growing season.

\begin{tabular}{l|cccccc}
\hline \multicolumn{1}{c|}{ Treatments } & GPR & PPR & NUE & NUPE & NUF & GY \\
\hline Conventional tillage & 12.92 & 4.23 & 174.9 & $19.90 \mathrm{~A}$ & $60.36 \mathrm{~B}$ & $2178.00 \mathrm{~A}$ \\
Reduced tillage & 11.98 & 4.56 & 71.8 & $9.87 \mathrm{~B}$ & $77.51 \mathrm{~A}$ & $1438.00 \mathrm{~B}$ \\
Mean & 12.45 & 4.39 & 123.35 & 14.88 & 68.93 & 1808.00 \\
$0 \mathrm{~kg} \mathrm{ha}^{-1} \mathrm{~N}$ & 11.93 & $3.73 \mathrm{~B}$ & & & & $1851.00 \mathrm{ab}$ \\
$50 \mathrm{~kg} \mathrm{ha}^{-1} \mathrm{~N}$ & 12.68 & $5.09 \mathrm{~A}$ & $186.8 \mathrm{~A}$ & $16.43 \mathrm{~A}$ & $126.30 \mathrm{~A}$ & $1654.00 \mathrm{~b}$ \\
$100 \mathrm{~kg} \mathrm{ha}^{-1} \mathrm{~N}$ & 12.95 & $4.44 \mathrm{AB}$ & $108.2 \mathrm{~B}$ & $11.50 \mathrm{~B}$ & $50.80 \mathrm{~B}$ & $1790.00 \mathrm{ab}$ \\
$150 \mathrm{~kg} \mathrm{ha}^{-1} \mathrm{~N}$ & 12.25 & $4.33 \mathrm{AB}$ & $75.0 \mathrm{C}$ & $16.72 \mathrm{~A}$ & $29.70 \mathrm{C}$ & $1935.00 \mathrm{a}$ \\
Mean & 12.45 & 4.39 & 123.35 & 14.88 & 68.93 & 1808.00 \\
\hline Tillage & $\mathrm{ns}$ & $\mathrm{ns}$ & $\mathrm{ns}$ & $* *$ & $* *$ & $* *$ \\
N doses & $\mathrm{ns}$ & $* *$ & $* *$ & $* *$ & $* *$ & $*$ \\
Tillage $\times \mathrm{N}$ doses & $\mathrm{ns}$ & $*$ & $* *$ & $* *$ & $* *$ & $* *$ \\
\hline
\end{tabular}

GBR: Grain protein ratio (\%); PPR: Plant protein ratio (\%); NUE: Nitrogen use efficiency (kg ha-1); NUPE: Nitrogen uptake efficiency (kg ha-1); NUF: Nitrogen utilization efficiency (kg ha-1); GY: Grain yield (kg ha-1); ns: non significant, *: $\mathrm{P} \leq 0.05, * *: \mathrm{P} \leq 0.01$. 


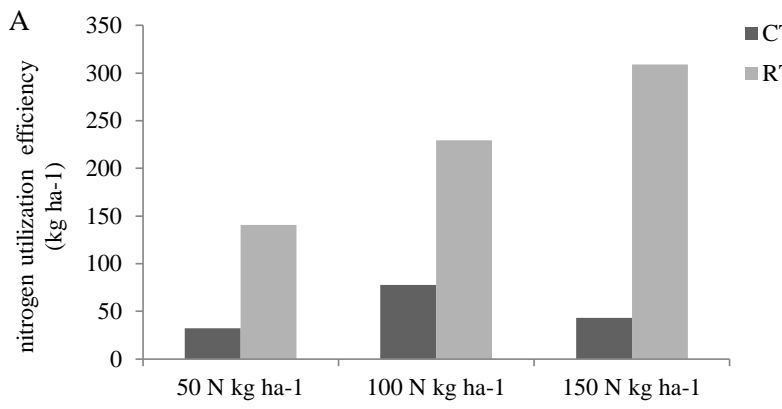

Figure 3. The interaction between tillage methods and $\mathrm{N}$ levels on nitrogen utilization efficiency (A) of wheat in 2011-2012 [ LSD1\%: $1.858(\mathrm{~A})]$
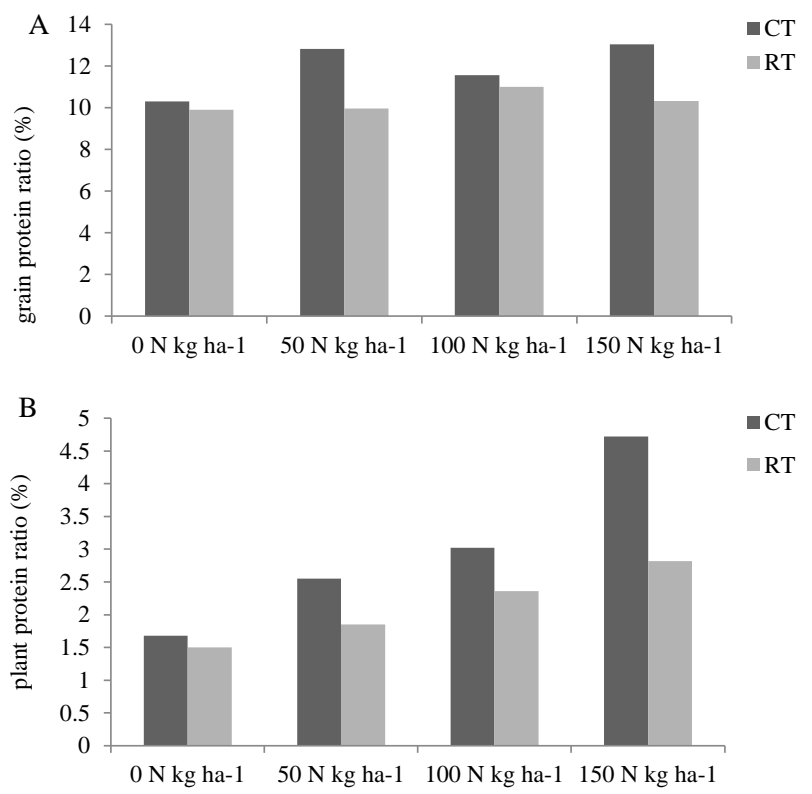

Figure 4. The interaction between tillage methods and $\mathrm{N}$ levels on grain protein ratio $(\mathrm{A})$ and plant protein ratio $(\mathrm{B})$ of wheat in 2012-2013[ LSD1\%: 1.212 (A); LSD1\%: 0.445 (B)]

A 180

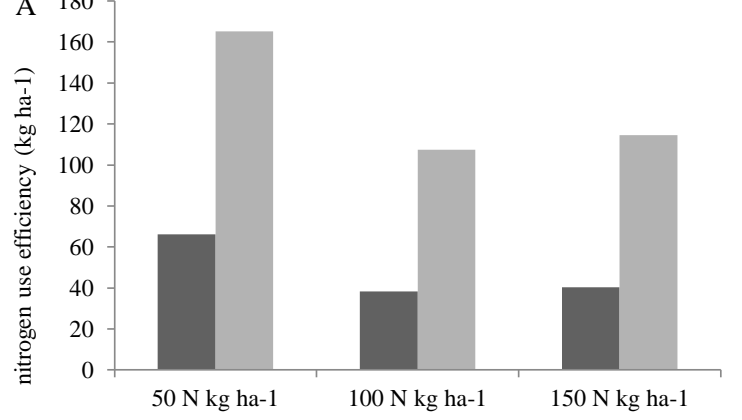

B

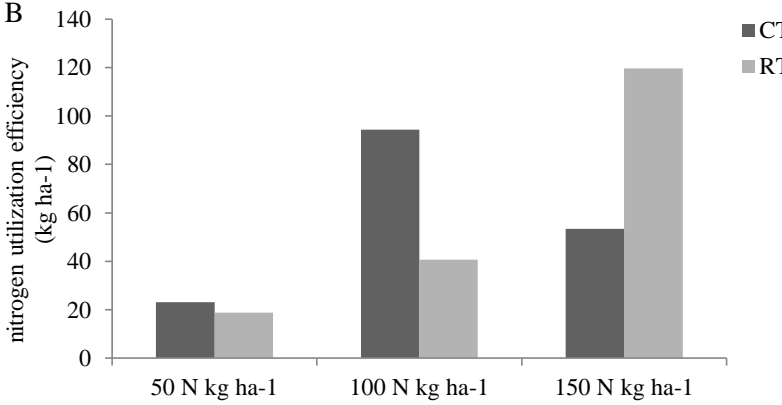

Figure 5. The interaction between tillage methods and $\mathrm{N}$ levels on nitrogen use efficiency (A) and nitrogen utilization efficiency (B) of wheat in 2012-2013[ LSD1\%: 1.803 (A); LSD\%1: 1.644 (B)]
The nitrogen uptake efficiency was higher in conventional tillage than reduced tillage in the 2012 2013, 2013 - 2014 and 2014-2015 growing seasons (Table $3,4,5)$. The NUPE was higher in conventional tillage than zero tillage according to findings of Lopez-Bellido and Lopez-Bellido (2001) and Rani et al. (2017). Brennan et al. (2015) noticed that the NUPE was higher in conventional tillage than reduced tillage. The NUPE showed the highest values in conventional tillage and $150 \mathrm{~kg} \mathrm{ha}^{-1} \mathrm{~N}$ levels in first year, although reduced tillage and $50 \mathrm{~kg} \mathrm{~N} \mathrm{ha}^{-1}$ dose showed the highest values (Figure 2B). While reduced tillage, wheat-wheat crop rotation and $50 \mathrm{~kg} \mathrm{ha}^{-1} \mathrm{~N}$ level had highest NUPE in the third growing season, the same nitrogen doses showed lower values in other plots (Figure 8B). Therefore, the interactions between applications were significant. The NUPE was not increased as parallel at $\mathrm{N}$ doses in both tillage methods, so "tillage x nitrogen dose" interactions was found significant (Figure 11A).

The nitrogen utilization efficiency was higher in reduced tillage than the conventional tillage in 2011-2012 and 2014-2015 growing seasons (Table 2, 5). Unlike the findings of this study, Rani et al. (2017) indicated that NUTE determined in traditional tillage. "Tillage $\mathrm{x}$ nitrogen dose" interactions were significant because NUTE increased in reduced tillage with increasing $\mathrm{N}$ doses, while it was irregular in conventional tillage at first and second years in experiment (Figure $3 \mathrm{~A}$ and $5 \mathrm{~B}$ ). In third year, the variability of NUTE according to crop rotation, tillage methods and $\mathrm{N}$ dosses was resulted significant "tillage $\mathrm{x}$ crop rotation $\mathrm{x}$ nitrogen dose" interaction (Figure 9A). For NUTE, $50 \mathrm{~kg} \mathrm{ha}^{-1} \mathrm{~N}$ levels showed superior performance under reduced tillage method in fourth growing season; however the NUTE was found the highest $100 \mathrm{~kg} \mathrm{ha}^{-1} \mathrm{~N}$ dose and conventional tillage. Moreover, the NUTE of both tillage methods in $150 \mathrm{~kg}$ ha- $1 \mathrm{~N}$ dose were close to each other (Figure 11B).

The grain yield was higher in reduced tillage than conventional tillage in 2012-2013 growing season (Table $3)$. The total precipitation and average temperature showed similar values to the long term in second year but total precipitation in April and May (49.4 $\mathrm{mm}$ ) is lower than the long term $(79.7 \mathrm{~mm})$ and the temperature was higher (Figure 1). The reduced tillage better protect the moisture in the soil (Page et al., 2019). Low precipitation and high temperatures during spring season might be increased evaporation and reduced tillage might be better protecting soil moisture. Therefore the grain yield might be higher in reduced tillage. The grain yield was lower than expected due to drought in 2013-2014 growing season (Table 4). While the long term total precipitation was $329.7 \mathrm{~mm}$, the total precipitation was $269.4 \mathrm{~mm}$ in this season (Figure 1). Even though the precipitation was very high during 20142015 growing season, the grain yield was lower in comparison to other years. The region was not received adequately precipitation in November and December (42.4 $\mathrm{mm}$ ) when after sowing and this precipitation was lower than the long term $(78.0 \mathrm{~mm})$ (Figure 1). Lower grain yield in this season might be drought after sowing. The grain yield was higher conventional tillage than reduced tillage in 2013-2014 and 2014-2015 growing seasons. The grain yield was highly variable according to tillage method, crop rotations, $\mathrm{N}$ doses, and years so significant interactions were found between them. 


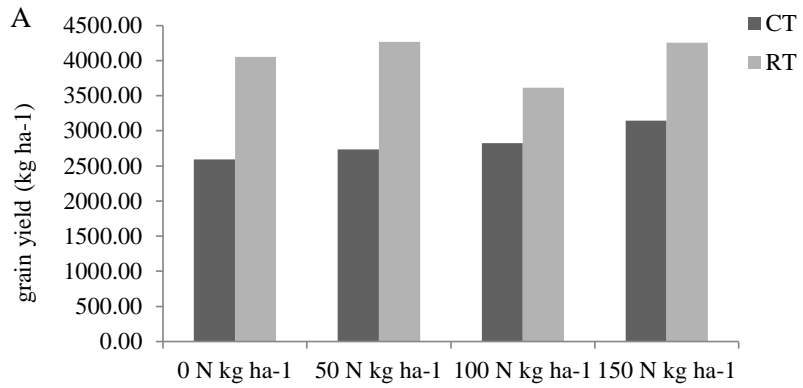

Figure 6. The interaction between tillage methods and $\mathrm{N}$ levels on grain yield (A) of wheat in 2012-2013[ LSD5\%: $43.450(\mathrm{~A})]$
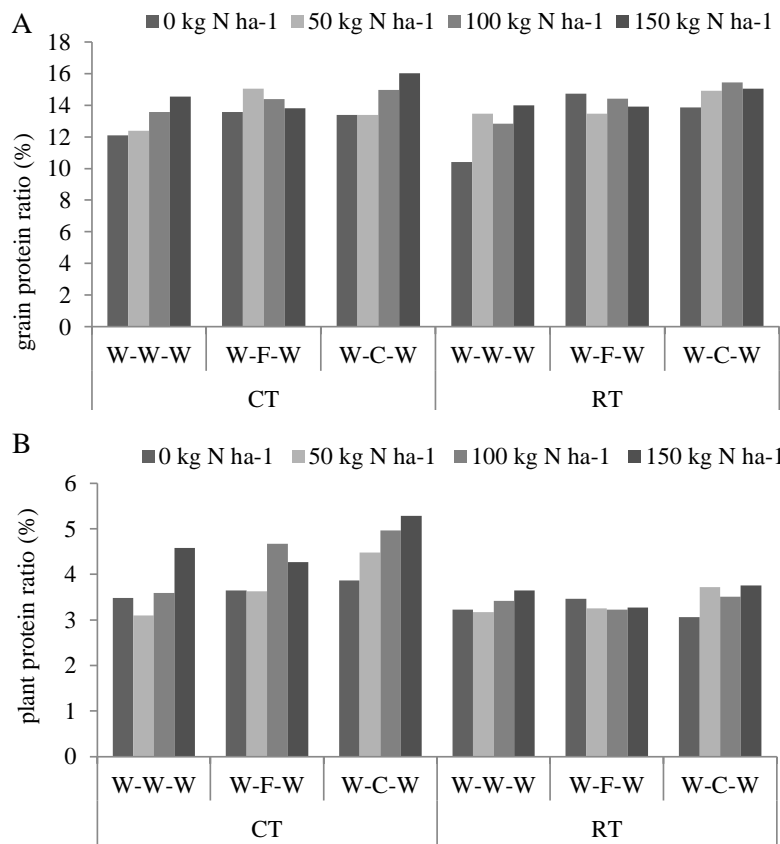

Figure 7. The interaction between tillage methods, crop rotations and $\mathrm{N}$ levels on grain protein ratio $(\mathrm{A})$ and plant protein ratio (B) of wheat in 2013-2014[ LSD1\%: 1.615 (A); LSD1\%: 0.279 (B)]

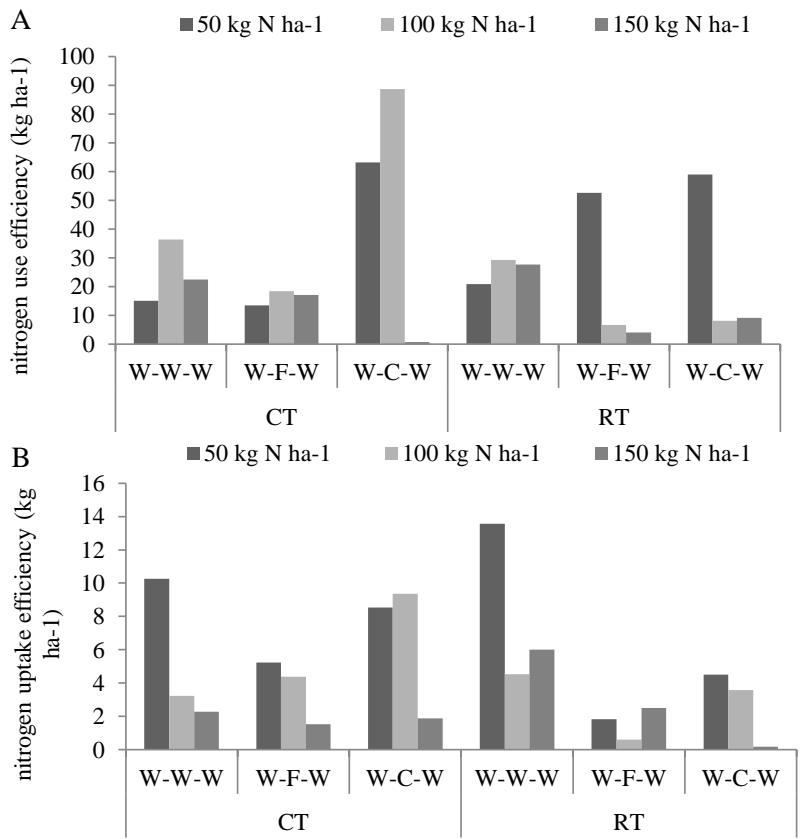

Figure 8 . The interaction between tillage methods, crop rotations and $\mathrm{N}$ levels on nitrogen use efficiency (A) and nitrogen uptake efficiency (B) of wheat in 2013-2014[ LSD1\%: 0.618 (A); LSD1\%: 0.077 (B)]
Although RT was at the forefront in some years, in general, the CT method, WCW crop rotation and $100 \mathrm{~kg} \mathrm{~N}$ $\mathrm{ha}^{-1}$ seemed suitable for high wheat yield (Figure 6A, 9B and 12A). Malecka et al. (2012), Wozniak (2013) and Ali et al. (2019) indicated that the grain yield was higher in conventional tillage than reduced tillage and zero tillage.

\section{Crop rotation}

The effects of different crop rotations were significantly for all of the investigated traits in 2013-2014 growing season (Table 4). The highest grain yield was obtained wheat-wheat crop rotation but it was taken within the same statistical group with the wheat-chickpea crop rotation system. Many researchers have suggested that there was significant increases in the cereals yield when cereals was sown after legumes and this increase was varied according to the type of legume that used as the preplant (Unver et al., 2001; Hao et al., 2001; Grant et al., 2016; Kirby et al., 2017). Fischer et al. (2002) found wheat yield close to each other in continuously wheat and wheatlegumes crop rotations.

The highest grain protein ratio, plant protein ratio and nitrogen use efficiency were obtained in wheat-chickpea rotation system. In wheat-legumes crop rotation than wheat-wheat and wheat-fallow crop rotations, higher wheat grain protein ratio was obtained by Lopez-Bellido et al. (1998) and Ali et al. (2019).

While the highest NUPE were obtained wheat-wheat crop rotation, the highest NUTE was obtained wheatfallow crop rotation. The highest NUE was determined in the wheat-chickpea crop rotation system. The legumes are suggested for higher NUE (Karasahin, 2014). Nitrogen use efficiency might be high due to high grain yield in wheatchickpea rotation. (Nitrogen use efficiency: Grain yield / applied N). Lopez-Bellido and Lopez-Bellido (2001) reported that the NUE, NUPE and NUTE were higher wheat-legumes rotation system comparison to the continuous wheat and wheat - fallow crop rotation systems.

\section{Fertilization}

Grain protein ratio was increased as $\mathrm{N}$ doses increased in 2011 - 2012 growing season. This increase was valid for both grain and plant protein ratio in the 2012 - 2013 and 2013 - 2014 growing season. The highest plant protein ratio was obtained at the $50 \mathrm{~kg} \mathrm{~N} \mathrm{ha}^{-1}$ in 2014-2015 growing season (Table 2, 3, 4, 5). The grain and plant protein ratio were higher than expected due to drought in third growing season. If there is low precipitation and high temperature after flowering, the grain yield reduced and the grain protein ratio raised (Panozzo and Eagles, 2000; Ozturk et al. 2006; Bulut, 2009; Sumer et al., 2010). Triboi et al. (2000) arqued that grain protein ratio is affected by nitrogen fertilization rather than genotype and environment. Many researchers (Abad et al., 2000; Ottman et al., 2000; Lopez-Bellido et al., 2004; Sumer et al., 2010) determined that increasing nitrogen doses were increased grain and plant protein ratio.

The NUE was decreased depending on the increasing nitrogen doses in 2012-2013, 2013-2014 and 2014- 2015 growing season (Table $3,4,5$.) There is a linear negative relationships between the N doses and NUE, viz the NUE is lower in high $\mathrm{N}$ doses (Ibrikci et al., 2001; Kamara et al., 
2003; Makino et al., 2003; Ev, 2006; Gouis et al., 2000; Semercioglu et al., 2009). Because, NUE is calculated by dividing grain yield to the applied $\mathrm{N}$ doses (Moll et al., 1982). The NUE was lower in third growing season comparison to other years however it higher in the fourth year. According to Muchow's findings (1994), the NUE and NUPE are affected air temperature and humidity and increased in higher temperature and humidity. The difference values of NUE between the years might be to climatic conditions, also low NUE in third growing season may be due to the low grain yield occurred because of drought (Figure 1).

Increasing $\mathrm{N}$ doses were decreased NUPE in all growing season (Table 2, 3, 4, 5). Nitrogen uptake efficiency is defined that the ratio of beneficial $\mathrm{N}$ in the soil to its amount taken by the plant (Karasahin, 2014). Nitrogen uptake efficiency was decreased to increasing $\mathrm{N}$ doses in previous researches (Ibrikci et al., 2001; Presterl et al., 2003; Kamara et al., 2003). When the excessive N application, the plant reaches to maximum saturation and residual $\mathrm{N}$ is washed. Therefore, excessive $\mathrm{N}$ fertilization is unnecessary to obtain high grain yield (Jokela and Randall, 1997). The NUPE was also determined similar to NUE to be very low in third growing season and very high in fourth growing season. In addition, the high $\mathrm{N}$ in soil might be caused higher NUPE.

The highest NUTE was observed at $150 \mathrm{~kg} \mathrm{~N} \mathrm{ha}^{-1}$ in 2011-2012 and 2012-2013, at $100 \mathrm{~kg} \mathrm{~N} \mathrm{ha}^{-1}$ in 2013-2014 and $50 \mathrm{~kg} \mathrm{~N} \mathrm{ha}^{-1}$ in 2014-2015 growing seasons. Kara (2006) and Maral (2009) determined that low NUTE in low $\mathrm{N}$ doses, while Kamara et al. (2003) found high NUTE in low $\mathrm{N}$ doses. In general, increasing $\mathrm{N}$ doses has been increased grain yield (Zaheer et al., 2015; Mansour et al., 2016; Haque et al., 2017; Gad et al., 2018).
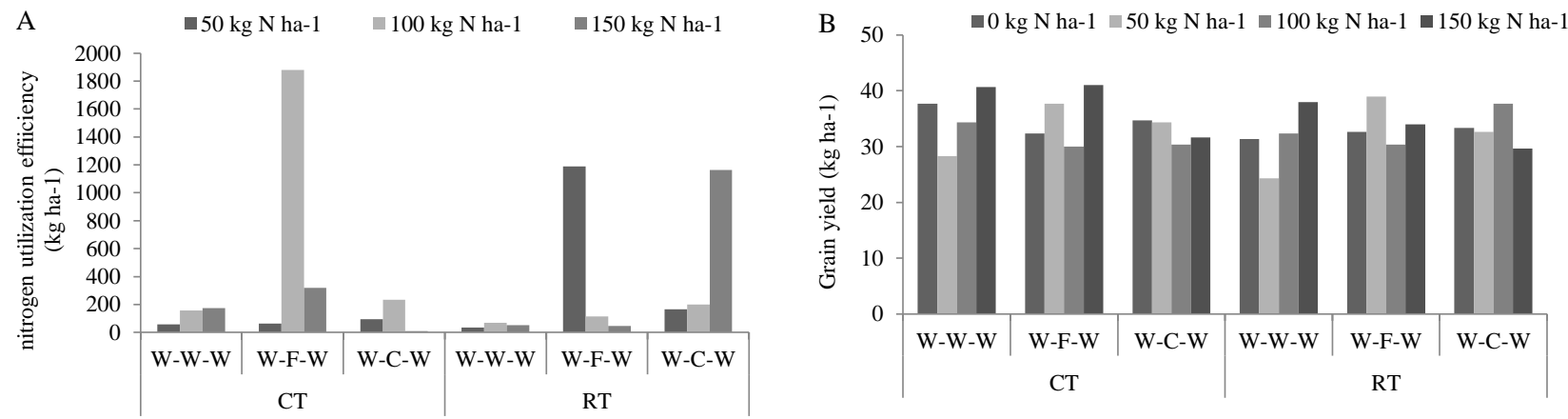

Figure 9. The interaction between tillage methods, crop rotations and $\mathrm{N}$ levels on nitrogen utilization efficiency (A) and grain yield (B) of wheat in 2013-2014[LSD1\%: 28.420 (A); LSD1\%: 16.574 (B)]
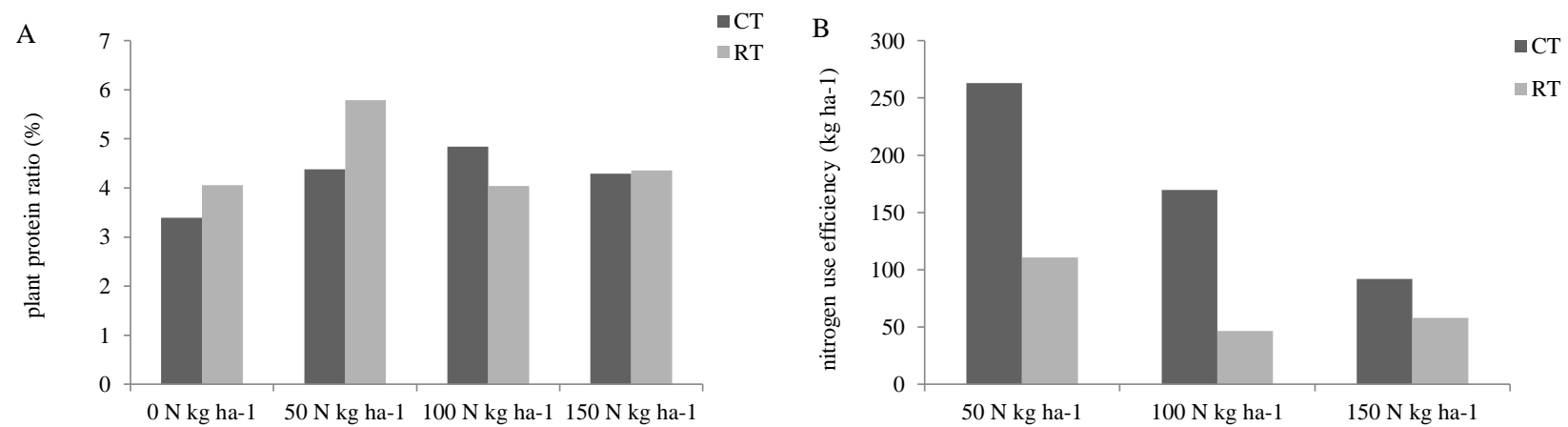

Figure 10. The interaction between tillage methods and $\mathrm{N}$ levels on plant protein ratio (A) and nitrogen use efficiency (B) of wheat in 2014-2015[ LSD5\%: 1.258 (A); LSD1\%: 6.397 (B) ]
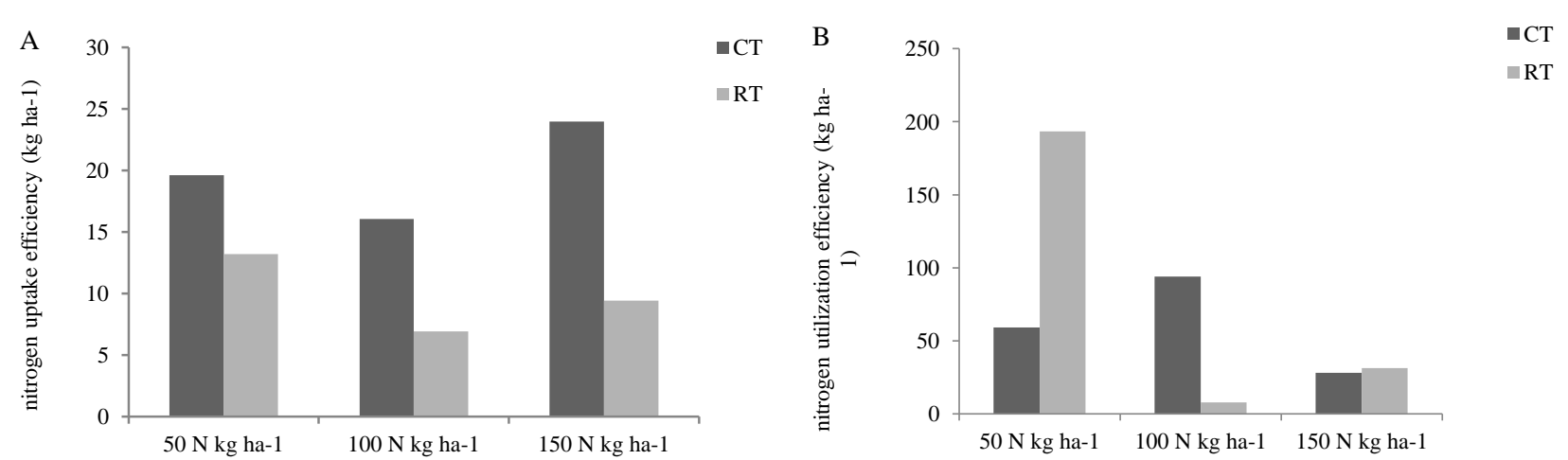

Figure 11. The interaction between tillage methods and $\mathrm{N}$ levels on nitrogen uptake efficiency (A) and nitrogen utilization efficiency (B) of wheat in 2014-2015[LSD5\%: 0.091 (A); LSD1\%: 0.668 (B)] 


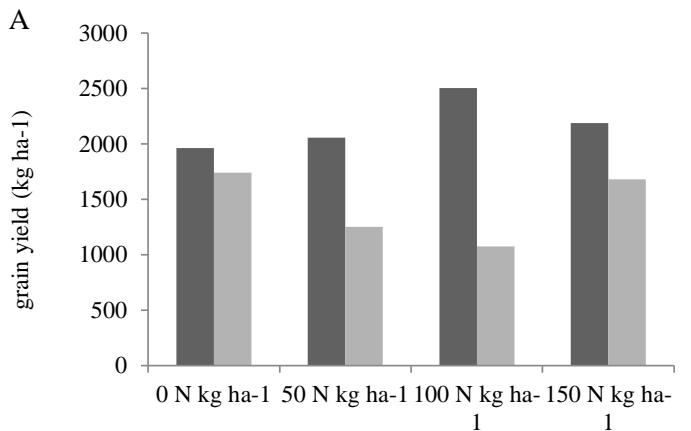

Figure 12. The interaction between tillage methods and $\mathrm{N}$ levels on grain yield (A) of wheat in 2014-2015[LSD1\%: $34.983(\mathrm{~A})]$

\section{Conclusion}

This study examined the effects of reduced and conventional tillage methods with applied together three different crop rotation and four $\mathrm{N}$ levels on yield, protein ratio, NUE, NUPE, and NUTE. The effect of tillage methods for grain yield and NUE is unclear, however examined traits improved mostly in conventional tillage. Generally, wheat-chickpea rotation system caused higher yield, protein ratio and NUE. Increasing $\mathrm{N}$ doses increased grain and plant protein ratio, while decreased NUE and NUPE. Also, $\mathrm{N}$ doses caused indeterminate reactions for grain yield and NUTE. These fluctuations might be occurred due to the different climatic conditions. Therefore, there is a need for more long-term studies. As a conclusion in this study, usually, the conventional tillage method, wheat-chickpea crop rotation and $100 \mathrm{~kg} \mathrm{~N}$ ha-1 seemed suitable for high wheat yield, protein ratio and NUEs.

\section{Acknowledgements}

This research was supported in part by Eskișehir Osmangazi University Research Foundation as Project no: 201123039.

\section{References}

Abad A, Loveras J, Michelena A, Ferran J, Royo C, Nachit MM, Fonzo N, Araus JL. 2000. Nitrogen fertilization effects on yield and quality of durum wheat in the Ebro Valley (Spain). In: Durum wheat improvement in the Mediterranean region: new challenges, Proceedings of a seminar, Zaragoza, Spain, Apr 12-14, pp. 575-577.

Adak MS, Birsin MA. 2000. Determination of some quality items and yield of the Gerek-79 wheat variety grown with different tillage methods and cropping systems. Journal of Agricultural Sciences, 6(4): 29-34.

Ali, SA, Tedone L, Verdini L, Cazzato E, De Mastro G. 2019. Wheat response to no-tillage and nitrogen fertilization in a long-term faba bean-based rotation, Agronomy, 9 (2): 50.

Baskan O, Unver I. 2000. The effect of depth of soil profile on fallow activity in Ankara conditions. Turk Journal of Agriculture and Forestry, 24: 721-727.

Brennan, JR, Forristal PD, McCabe T, Hackett R. 2015. The effect of soil tillage system on the nitrogen uptake, grain yield and nitrogen use efficiency of spring barley in a cool Atlantic climate. Journal of Agricultural Science, 153: 862-875.
Bulut S. 2009. The effects of different fertilizer sources and plant growth in organic wheat planting on yield and quality. $\mathrm{PhD}$. Dissertation. Institute of Natural and Applied Sciences, Atatürk University, Erzurum, Turkey.

Delagu G, Cattivelli L, Pecchioni N, De Falcis D, Maggiore T, Stanca A M. 1998. Uptake and agronomic efficiency of nitrogen in winter barley and winter wheat. European Journal of Agronomy, 9: 11-20.

Devi P, Aggarwal A, Gupta SR. 2015. Effect of zero tillage on soil carbon storage and nitrogen uptake in rice-wheat systems in Northern India. American-Eurasian Journal of Agricultural \& Environmental Sciences, 15 (5): 923-931.

Ev O. 2006. Effect of nitrogen fertilizers on yield and quality of some bread and durum wheat varieties in Konya conditions. Msc Dissertation. Institute of Natural and Applied Sciences, Trakya University, Tekirdag, Turkey.

Fischer RA, Santiveri F, Vidal IR. 2002. Crop rotation, tillage and crop residue management for wheat and maize in the subhumid tropical highlands I. wheat and legume performance. Field Crops Research, 79: 107-122.

Gad, AB, Shalaby MM, Hassanein HG, Ali EA, Said MT. 2018. Effect of preceding crop, rates and splitting of nitrogen fertilizer on bread wheat production and nitrogen use efficiency. Journal of Plant Production, 9(8), 663-669.

Genctan T. 2015. Tarla Tarımı, Namık Kemal Üniversitesi Ders Kitab1, Yayın No: 11, 386 p.

Gouis JL, Beghin D, Heumez E, Pluchard P. 2000. Genetic differences for nitrogen uptake and nitrogen utilisation efficiencies in winter wheat. European Journal of Agronomy, 12: 163-73.

Ghiyasi M, Amirnia R, Rezaei-Chiyaneh E. 2016. Alternatif toprak sürme modellerin agro ekosistem biyoçeşitliliği üzerine etkisi. Türk Bilimsel Derlemeler Dergisi, 9 (2): 3940.

Grant CA, O’Donovan JT, Blackshaw RE, Harker KN, Johnson EN, Gan Y, McLaren DL. 2016. Residual effects of preceding crops and nitrogen fertilizer on yield and crop and soil $\mathrm{N}$ dynamics of spring wheat and canola in varying environments on the Canadian prairies. Field Crops Research, 192: 86-102.

Hao X, Chang C, Conner RL, Bergen P. 2001. Effect of minimum tillage and crop sequence on crop yield and quality under irrigation in a southern Alberta clay loam soil. Soil and Tillage Research, 59: 45-55.

Haque ANA, Hossain ME, Haque ME, Hasan MM, Malek MA, Rafii MY, Shamsuzzaman SM. 2017. Response of yield, nitrogen use efficiency and grain protein content of wheat (Triticum aestivum L.) varieties to different nitrogen levels. Bangladesh Journal of Botany, 46 (1): 389-396.

Ibrikci H, Ulger AC, Sen HM, Buyuk G, Guzel N, Cakir B, Ozgenturk G. 2001. Optimization of Nitrogen Fertilizer Usage in Corn Cultivation of Second Product in Çukurova Region. TUBITAK: Final Result Report, Adana.

Jabran K, Aulakh AM. 2015. Higher yield and economic benefits for wheat planted in conservation till systems. Yüzüncü Y1l Üniversitesi Tarım Bilimleri Dergisi, 25 (1): 78-83.

Jokela WE, Randall GW. 1997. Fate of fertilizer nitrogen an affected by time and rate of application on corn. Soil Science Society of America Journal, 61:1695-1703.

Jones DIH. 1981. Chemical Composition and Nutritive Value, In: Handson J, Baker RD, Davies A, Laidlow AS, Leawer JD (editors). Sward Measurement Handbook. Kenilworth. UK: The British Grassland Society Press; p. 243-265.

Kamara AY, Menkir A, Sanginga N. 2003. Nitrogen use efficiency of maize genotypes improved for tolerance to low nitrogen and drought stress. International Institute of Tropical Agriculture, Ibadan, Nigaria.

Kara B. 2006. Determination of the efficiency and yield characteristics of corn and nitrogen uptake and utilization efficiency in various plant frequencies and different nitrogen doses in Cukurova conditions. PhD. Dissertation. Institute of Natural and Applied Sciences, Cukurova University, Adana, Turkey. 
Karasahin M. 2014. Nitrogen uptake efficiency in plant production and negative effects on reactive nitrogen environment. Journal of Academic Platform, Engineering and Science, 2 (3): 15-21.

Kirby E, Pan W, Huggins DR, Painter KM, Bista P, Yorgey G, Kruger C. 2017. Rotational diversification and intensification. Advances in Dryland Farming in the Inland Pacific Northwest, 163-236.

Kun E, Altay F, Kalaycı M, Adak MS, Tusuz A, Acıkgoz N, Tugay ME, Sencar O, Meyveci K, Tan A, Kurt O, Karagoz A. 1990. Narrowing of fallow fields in Turkey and second product studies. In: Turkey Agricultural Engineering 3rd Technical Congress, Ankara, Turkey, 8-12 January 1990, pp. 62-85.

Lopez-Bellido L, Fuentes M, Castillo JE, Lopez-Garrido FJ. 1998. Effects of tillage, crop rotation and nitrogen fertilization on wheat-grain quality grown under rain-fed Mediterranean conditions. Field Crops Research, 57: 265276.

Lopez-Bellido RJ, Lopez-Bellido L. 2001. Efficiency of nitrogen in wheat under Mediterranean conditions: effect of tillage, crop rotation and $\mathrm{N}$ fertilization. Field Crops Research, 71: 31-46.

Lopez-Bellido RJ, Lopez-Bellido L, Castillo JE, Lopez-Bellido FJ. 2004. Chickpea response to tillage and soil residual nitrogen in a continuous rotation with wheat II. Soil nitrate, $\mathrm{N}$ uptake and influence on wheat yield. Field Crops Research, 88: 201-210.

Makino AH, Sakuma ES, Mae T. 2003. Differences between maize and rice in n-use efficiency for photosynthesis and protein allocation. Plant and Cell Physiology, 44 (9): $952-$ 956.

Malecka I, Blecharczyk A, Sawinska Z, Dobrzeniecki T. 2012. The effect of various long-term tillage systems on soil proporties and spring barley yield. Turkish Journal of Agriculture and Forestry, 36: 217-226.

Mansour HA, Pibars S, Gaballah MS, Mohammed KAS. 2016. Effect of different nitrogen fertilizer levels, and wheat cultivars on yield and its components under sprinkler irrigation system management in sandy soil. International Journal of ChemTech Research, 9 (9): 1-9.

Maral H. 2009. Response to nitrogen fertilization, nitrogen utilization and yield characteristics of oat varieties. Msc. Dissertation. Institute of Natural and Applied Sciences, Kahramanmaras Sutcu Imam University, Kahramanmaras, Turkey.

Moll RH, Kamprath EJ, Jackson WA. 1982. Analysis and interpretation of factors which contribute to efficiency of nitrogen utilization. Agronomy Journal, 74: 562-564.

Muchow RC. 1994. Effect of nitrogen on yield determination in irrigated maize in tropical and subtropical environments. Field Crops Research, 38(1): 1-13.

Ottman MJ, Doerge TA, Martin EC. 2000. Durum grain quality as affected by nitrogen fertilization near anthesis and irrigation during grain fill. Agronomy Journal, 92(5): 10351041.

Oztürk A, Caglar O, Bulut S. 2006. Growth and yield response of facultative wheat to winter sowing, freezing sowing and spring sowing at different seeding rates. Journal of Agronomy and Crop Science, 192: 10-16.
Panozzo JF, Eagles HA. 2000. Cultivar and environmental effects on quality characters in wheat. II. Protein. Australian Journal of Agricultural Research, 51: 629-636.

Page KL, Dang YP, Dalal RC, Reeves S, Thomas G, Wang W, Thompson JP. 2019. Changes in soil water storage with notillage and crop residue retention on a Vertisol: Impact on productivity and profitability over a 50 year period. Soil and Tillage Research, 194, 104319. https://doi.org/10.1016/j.still.2019.104319

Presterl T, Seitz G, Landbeck M, Thiemt EM, Schmidt W, Geiger HH. 2003. Improving nitrogen-use efficiency in European maize: estimation of quantitative genetic parameters. Crop Science, 43:1259-1265.

Rani A, Bandyopadhyay KK, Krishnan P. 2017. Simulation of Nitrogen Uptake, Nitrogen Utilization Efficiency and Yield of Wheat under Tillage, Residue and Nitrogen Management using DSSAT-CERES-Wheat Model. The Indian Ecological Society, 44(2), 167-178.

Ruisi P, Saia S, Badagliacca G, Amato G, Frenda A S, Giambalvo D, Miceli GD. 2016. Long-term effects of no tillage treatment on soil $\mathrm{N}$ availability, $\mathrm{N}$ uptake and $15 \mathrm{~N}$ - fertilizer recovery of durum wheat differ in relation to crop sequence. Field Crop Research, 189: 51-58.

Ruiz M, Zambrana E, Fite R, Sole A, Tenorio JL, Benavente E. 2019. Yield and quality performance of traditional and improved bread and durum wheat varieties under two conservation tillage systems. Sustainability, 11(17), 4522.

Semercioğlu T, Barut H, Keklikçi Z, Aykanat S. 2009. Determination of the nitrogen utilization efficiencies (NUE) and the most suitable variety of bread and pasta wheat cultivated widely in Cukurova. Poster session presented at: Turkey 8th Field Crops Congress, Hatay, Turkey, 19-22 October 2009.

Sowers KE, Miller BC, Pan WL. 1994. Optimizing grain yield in soft white winter wheat with split nitrogen applications. Agronomy Journal, 86:1020-1025.

Sumer FO, Erekul O, Koca YO. 2010. Effect of plant frequency and nitrogen doses on yield, yield factors and bread quality characteristics of different wheat (Triticum aestivum L.) varieties. Anadolu Journal of Agronomy, 20 (2): 28 - 44.

Thériault L, Dessureault-Rompré J, Caron J. 2019. Short-term improvement in soil physical properties of cultivated histosols through deep-rooted crop rotation and subsoiling. Agronomy Journal, 111(4), 2084-2096.

Triboi E, Abad A, Michelena A, Lloveras J, Ollier JL, Daniel C. 2000. Environmental effects on the quality of two wheat genotypes: 1. quantitative and qualitative variation of storage proteins. European Journal of Agronomy, 13:47 64.

Unver S, Kaya M, Atak M, Hakyemez HB. 2001. Yield and yield components in wheat after winter Hungarian vetch in Central Anatolian conditions. Turkish Journal of Agriculture and Forestry, 25: 247-256.

Wozniak A. 2013. The effect of tillage systems on yield and quality of durum wheat cultivars. Turkish Journal of Agriculture and Forestry, 37: 133-138.

Zaheer S, Ahmed A, Jan A, Akhtar K, Ha VN. 2015. Effect of nitrogen and preceding cropping pattern on yield and yield components of rainfed wheat. Journal of Environment and Earth Science, 5 (11): 47-55. 